\title{
Fish bile and cautery: trachoma treatment in art
}

\author{
Horton A Johnson MD
}

J R Soc Med 2005;98:30-32

The biblical story of Tobias, who cured his blind father Tobit with the bile of a fish, was a popular theme among European painters of the 16 th and 17 th centuries. The tale, with its message of religious faith, filial devotion, drama, and miracle, inspired Rembrandt, Jan Massys, de Vos, van Hemessen, Carracci, Carlone, Assereto, Feti, Guardi and Strozzi. An early representation is a woodcut in the 'Zurich Bible' of 1536.

The painting by Bernardo Strozzi (1581-1644) in the Metropolitan Museum of Art, New York (Figure 1), shows Tobias applying fish bile to his father's eyes, while his aged mother Anna, the youthful archangel Raphael, and the dog look on. The interplay of intense gazes and expressive hands conveys the excitement of the moment. The fish, its belly opened, lies in the foreground. Strozzi painted this in the 1630 s during his Venetian period. It is a replica of an earlier painting from his Genoese period now in the Cleveland Museum of Art. The cure of Tobit seems to have been among Strozzi's favourite subjects, because he painted some eight other versions and replicas of the same scene, including a well-known version in the Hermitage, St Petersburg. ${ }^{1}$ These works were based upon Apocrypha, The Book of Tobit. ${ }^{2}$

"Then Raphael said to Tobias, "Take the gall of the fish with you ... I know, Tobias, that your father will open his eyes. You therefore must anoint his eyes with the gall, and when they smart he will rub them, and will cause the white films to fall away, and he will see you:" Then Anna ran to meet them, and embraced her son, and said to him, "I have seen you, my child; now I am ready to die." And they both wept. Tobit started toward the door and stumbled. But his son ran to him and took hold of his father, and he sprinkled the gall upon his father's eyes, saying, "Be of good cheer, Father". And when his eyes began to smart he rubbed them, and the white film scaled off from the corners of his eyes. Then he saw his son and embraced him, and he wept and said, "Blessed art thou, O God, and blessed is thy name forever, and blessed are all thy holy angels." , _ Tobit 11.2-14

Three Lincoln Center \#47C, New York, NY 10023-6566, USA

E-mail: horton_Johnson@hotmail.com

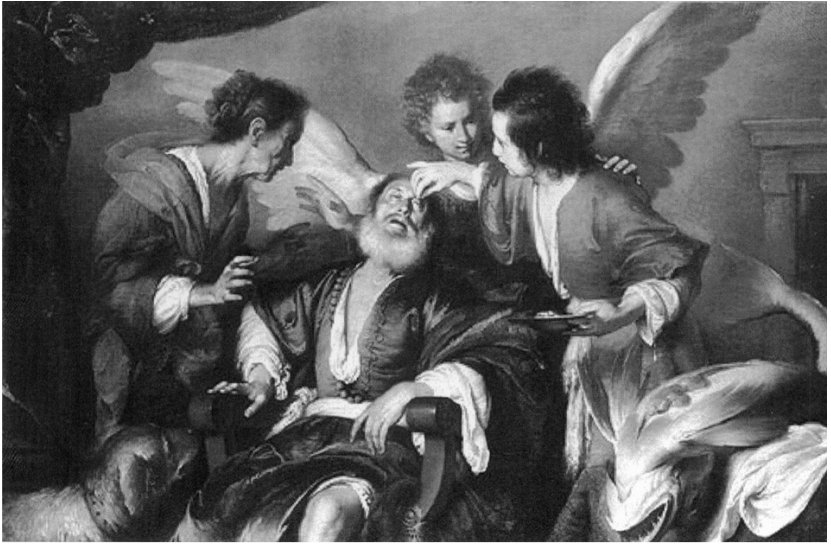

Figure 1 Bernardo Strozzi. Tobias Curing His Blind Father, Tobit. Metropolitan Museum of Art, reproduced by permission

The 'white film' that 'scaled off from the corners of his eyes' corresponds to the exudate of a purulent conjunctivitis. In ancient as well as recent times, the prevalent blinding conjunctivitis in the Middle East was due to Chlamydia trachomatis. In the inflammatory stage of trachoma, blindness is due to pannus formation, the overgrowth of the cornea by vessels from the limbus. In the case of Tobit, the rapidity of the cure was miraculous, but the use of fish bile was probably based upon a common practice at the time - a practice that may in fact have aided the resolution of pannus and the restoration of vision.

Bile, irritating as it is to the eye, was evidently a traditional trachoma remedy that met with some success, because it remained in use for another two thousand years. It was recommended in the first century CE by the Roman encyclopaedist Celsus, who wrote that 'goat's bile... is suitable enough for the treatment of trachoma' ${ }^{3}$ (he used the word aspritudo [ocularum] which, like the Greek trachoma, describes the roughness of the inner lids caused by hyperplastic lymphoid follicles). Even after Paracelsus had rejected most of Galenian Roman medicine in the 16th century, his followers still persisted in using bile for the treatment of trachoma. In the 17th century the Dutchman van Foreest, the German Sennert, and the Syrian Ibn Sallum all prescribed for trachomatous pannus a concoction that included eel bile and ox bile. ${ }^{4}$

Until the discovery of the bacterial cause of trachoma and its treatment with antibiotics in the mid-20th century, the accepted treatment was little changed. In 1949, one of the most widely used textbooks of ophthalmology, May's 
Manual of the Diseases of the Eye, ${ }^{5}$ directed that the inflammatory stage of trachoma, which was 'due to a filterable virus,' should be treated with 'irritating applications' - evidently following the homeopathic principle of treating an inflammation with an inflammatory agent. The text claimed that with the aid of such 'irritating applications' the blinding pannus could regress completely, making the cornea transparent again. In light of this, the story of Tobit becomes plausible. May's Manual, which preferred copper sulphate among a number of suggested irritating applications, did not mention bile specifically, but it does not seem an altogether bad idea.

Initial infection of the eye by C. trachomatis causes a purulent conjunctivitis which can heal without permanent sequelae. ${ }^{6}$ After years of reinfection, however, conjunctival scarring develops with contracture of the inner surface of the lid, most often the upper lid, causing trichiasis - the rolling of the lashes inward upon the cornea. The painful scratching of the cornea by the lashes eventually leads to corneal ulceration, scarring, opacity and permanent blindness. The Romans treated trichiasis surgically, and the result of such a procedure can be seen in a portrait painted in Roman Egypt around 200 CE.

In the Fayyum district of the Nile valley, some $80 \mathrm{~km}$ southwest of Cairo, hundreds of 'mummy portraits' have been discovered. Facial portraits, evidently made during life, were painted on wooden or canvas panels that overlay the wrapped faces of the mummies. The portraits were painted in encaustic - beeswax with bright mineral pigments - and are sometimes breathtaking in their realism. ${ }^{7}$

One of these, in the Metropolitan Museum of Art (Figure 2), shows a young man whose right lower eyelid is deformed. Lehrman has judged the deformity to be the result of trachoma, which had been endemic in the Nile valley since before the Ebers papyrus (c. 1550 BCE). ${ }^{8}$ However, Lehrman did not recognize that the painting also shows the result of what has been accepted more recently as an ancient blepharoplasty: the surgical basis of the lid deformity was pointed out by Dr David T Mininberg. The only sight-saving treatment for chronic trachoma was, as it is today, the surgical correction of trichiasis. The portrait is now presented as a Youth With a Surgical Cut in the Right Eye. The right lower lid (Figure 3) is discoloured and fixed in a partly closed position. The margin is unnaturally straight, as though under tension of contracted scar tissue. The lashes of that lid, and only that lid, are entirely missing, apparently having been removed therapeutically. The lid margin, along with the lashes, could simply have been excised, but cauterization is more likely than a 'surgical cut'. At the time of the painting the 'state of the art' treatment of trichiasis in Graeco-Roman-Alexandrian medicine was cautery, a painful but bloodless procedure. That would have been

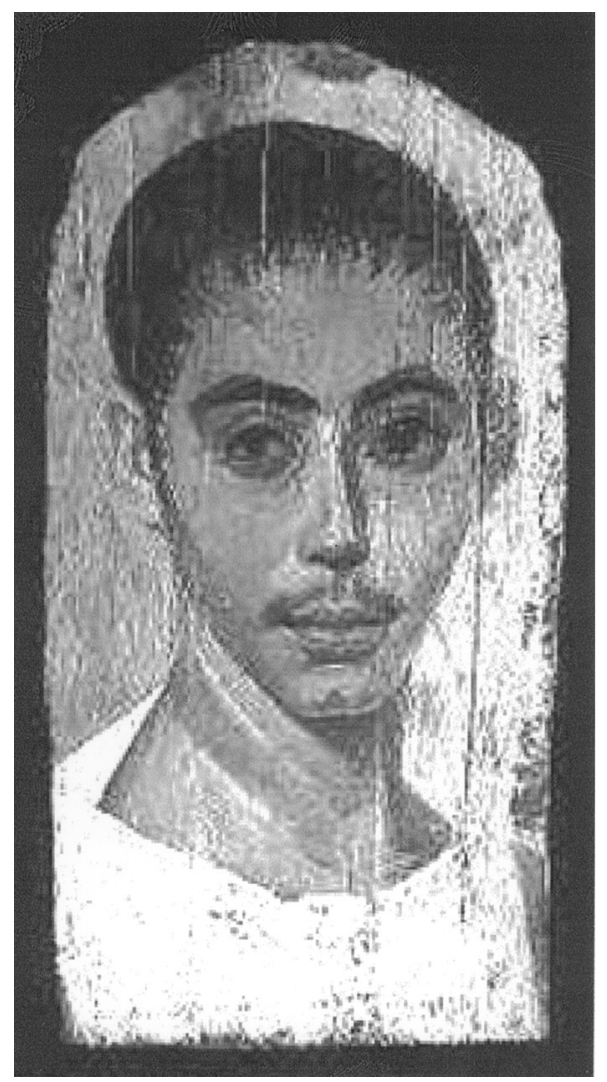

Figure 2 Youth With a Surgical Cut in the Right Eye (Egyptian c. 190-210 CE). Metropolitan Museum of Art, reproduced by permission

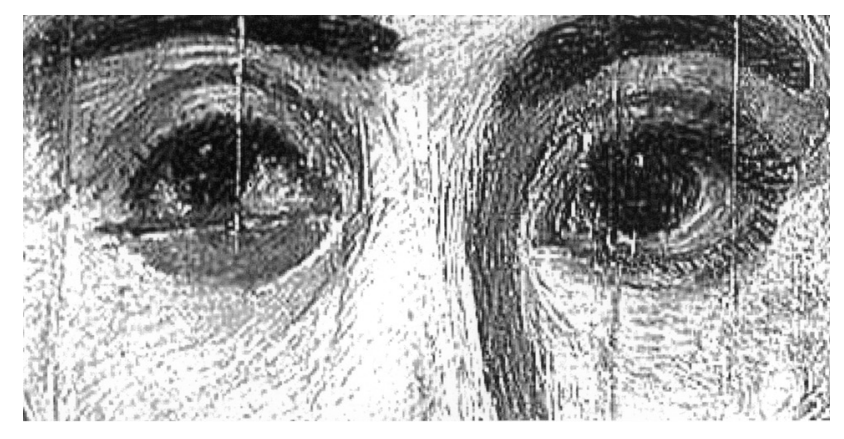

Figure 3 Detail of Figure 2

the best treatment available to the affluent of the Nile valley. Celsus has given a chilling description of this procedure in Chapter VII of his De Medicina:

'If eyelashes have grown where they ought not, a fine iron needle flattened like a spear point is put into the fire; then when the eyelid is turned out, so that the offending eyelashes can be seen by the operator, the red hot needle is passed along their roots, from the angle, for a third of the length of the eyelid, then for a second and for a third time, until the opposite angle is reached; this causes all the roots of the eyelashes so cauterized to die. 
A medicament is then applied to check inflammation, and when the crusts have become detached, cicatrization is to be induced. This kind of trouble is very easily cured.' ${ }^{3}$

Scar tissue, probably due to cautery, lines the margin of the right lower lid of the young Egyptian. If the portrait is accurate, the red-hot spear-like needle has accidentally moved slightly beyond the lid and has left an extended scar in the skin of the lateral angle. The lashes, their roots cauterized, have fallen out. The trichiasis has been cured even if vision has not been saved. The pupil is out of alignment and the eye is probably blind, but the terrible pain of the corneal abrasion and ulceration has been relieved. The artist has made no attempt to hide or minimize the deformity of the lid, which may even have been tolerated as a mark of distinction.

It is not surprising that $C$. trachomatis, a leading cause of blindness in the developing world and of sexually transmitted disease in the developed world, should also have its place in the art world. And so it is that on the walls of art museums one can study the ancient treatment of trachoma in both its inflammatory and cicatricial stages - a remarkable artistic acknowledgment of that very small, gram-negative, obligate intracellular bacterium.

\section{REFERENCES}

1 Chong A. Bernardo Strossi: The healing of Tobit. Bull Cleveland Museum of Art 1993;80:154-7

2 The Apopcrypha: New Revised Standard Version. Cambridge: Cambridge University Press, 1998

3 Celsus AC. De Medicina. Loeb Classical Library (trans. WG Spencer). Cambridge, MA: Harvard University Press, 1935

4 Savage-Smith E. Drug therapy of eye diseases in seventeenth century Islamic medicine - the influence of the "new chemistry" of the Paracelsians. Pharmacy in History 1987;29:3-28

5 Perera CA. May's Manual of the Diseases of the Eye. 20th edn. Baltimore: Williams \& Wilkins, 1949:124-7

6 Mabey DCW, Solomon AW, Foster A. Trachoma. Lancet 2003;362: 223-9

7 J E Berger Foundation. Roman Portraits from Egypt: The Eye and Eternity [http://www.bergerfoundation.ch/Fayoum]

8 Lehrman A. The Fayyum portraits. Plast Reconstr Surg 1993;92:378-9 